\title{
Eudaimonisme og anti-eudaimonisme
}

\author{
Grundrids af striden om den rene kærlighed (1693-1699)
}

\section{Ph.d. Kenneth Berg}

\begin{abstract}
The quality of disinterestedness is generally thought to be the defining feature of the moral act. As a result, much of modern moral thinking promotes some idea of self-sacrifice. It is the contention of the present article that this tendency is unfortunate. At the same time, it suggests that the opposite view - namely that human beings are by nature ineradicably selfish - is equally problematic. The article traces the origins of these two positions to the quarrel over pure love at the end of the $17^{\text {th }}$ century and discusses the views of its two main protagonists, François Fénelon and Jacques-Bénigne Bossuet. In the final third, the article turns to the $20^{\text {th }}$ century, particularly to German philosopher Robert Spaemann. It thereby includes a suggestion of how the modern paradigm of disinterestedness may be dissolved through a phenomenological analysis of love.
\end{abstract}

Key words: Disinterestedness - self-sacrifice - psychological egoism - the history of moral thinking $-17^{\text {th }}$-century theology.

Artikels omdrejningspunkt er den teologiske strid om den rene kærlighed (la querelle du pur amour), "måske den sidste store teologiske debat i kristendommens historie". ${ }^{1}$ Dens ærinde er at give et bidrag til den nutidige diskussion om den interesseløse handling eller den rene gave. De følgende sider hviler mere præcist på den opfattelse, at moderne moraltænkning på en uheldig måde oscillerer mellem to lige uholdbare positioner: på den ene side hævdelsen af menneskets naturnødvendige selviskhed, på den anden side fejringen af den fuldstændige interesseløshed som menneskets højeste potentialitet. ${ }^{2}$ Det er artiklens hensigt at pege på, hvordan de to modstridende synspunkter tydeligt tog form i løbet af den nævnte strid. Det vil ske først igennem en analyse af begrebet om den rene kærlighed (1. hovedafsnit), dernæst igennem en betragtning af de involverede teologers for-

1. Jacques Le Brun, Le Pur Amour de Platon à Lacan (Paris: Seuil 2002), 9. Alle oversættelser er mine egne.

2. Se henvisningerne n. 39 . 
valtning af den forudgående tradition (2. hovedafsnit). Endelig vil artiklen indeholde en diskussion af det forsøg på en overskridelse af den nævnte modsætning, som findes hos den tyske filosof og Fénelon-kender Robert Spaemann (3. hovedafsnit).

\section{Den rene kærlighed}

Den kirkehistoriske baggrund for striden om den rene kærlighed er processen imod den spanske kleriker Miguel de Molinos. ${ }^{3}$ Hans fordømmelse i Rom i 1687 satte dagsordenen for den kirkelige debat indtil århundredets afslutning. Stemningen var således til et opgør med den mystiske strømning i teologien, da François Fénelon (16511715) i 1688 første gang mødte Jeanne Guyon (1648-1717). Han var præst og doktor i teologi, fra 1695 ærkebiskop af Cambrai, hun var en åndelig vakt enke, der allerede havde siddet indespærret for de synspunkter, hun udbredte. I forbindelse med striden om den rene kærlighed skulle hun igen blive arresteret og sidde fanget $\mathrm{i}$ en anselig årrække, bl.a. i Bastillen. Trods sin kontroversielle person gjorde Jeanne et stærkt indtryk på sit nye bekendtskab og fik ham ikke mindst overbevist om den resurse, der lå hos de moderne kristne mystikere. ${ }^{4}$ Hendes indflydelse ved kredse omkring hoffet (hvor Fénelon indtog posten som huslærer for kronprinsens søn) tiltrak sig dog med tiden en uheldig grad af opmærksomhed. Striden om den rene kærlighed tog dermed sin begyndelse som Fénelons teologisk artikulerede forsvar for sin veninde, i første omgang i forbindelse med en række teologiske samtaler (les conférences d'Issy), siden gennem en lang serie af skrifter og åbne breve som svar på hans kritikere. ${ }^{5}$

3. En god gennemgang af hele affæren fra Molinos til Fénelon kan findes i Le Brun, "Quiétisme", Dictionnaire de spiritualité. Ascétique et mystique. Doctrine et histoire, bd. 12, 2. del, 2755-2842 og i Jean-Robert Armogathe, Le quiétisme (Paris: P.U.F 1973).

4. Når jeg hentyder til den kristne mystik, antager jeg ikke noget om en særegen mystisk erfaringsverden, men alene om eksistensen af en bestemt tematik, der kredser om menneskets tab af sig selv. Se Mino Bergamo, La science des saints. Le discours mystique au XVIIe siècle en France (Grenoble: Jérôme Millon 1992), 1519. Jf. også Michel de Certeau, "'Mystique' au XVIIe siècle. Le problème du langage 'mystique", L'homme devant Dieu. Mélanges offerts au Père Henri de Lubac. Du Moyen Âge au siècle des Lumières, Théologie 57 (Paris: Aubier 1964).

5. Jeg henviser i det følgende til François de Salignac de la Mothe-Fénelon, Euvres complètes précédées de son histoire littéraire par M. Gosselin, 10 bd. (Geneva: Slatkine Reprints 1971 [Paris 1851-1852]; herefter OF) og CEuvres, Bibliothèque de la Pléiade, udg. Le Brun, 2 bd. (Paris: Gallimard 1983-1997; herefter EP). Hvor en tekst ikke findes i EP, henviser jeg til OF. Som en god introduktion til Fénelon kan nævnes Henri Gouhier, Fénelon philosophe (Paris: Vrin 1977). 
En række kristne mystikere, både de rhinlandske og de spanske, spiller en betydelig rolle i det system, som Fénelon udviklede. Det er bl.a. vigtigt at være opmærksom på, hvordan den kristne mystik hos Fénelon kan betragtes som et svar på et moralsk og religiøst ubehag, der er kendetegnende for perioden som sådan. Nogle af tidens mest populære forfattere - ud over François de La Rochefoucauld f.eks. Blaise Pascal og Pierre Nicole - havde således opdyrket en særlig interesse i menneskets motiver. Resultatet havde været en form for moralsk skepsis. Den gængse tese mod århundredets slutning var simpelthen, at mennesket ante gratiam ikke handler, uden at det er til egen fordel, selv ikke når det virker til at være styret af de ædleste motiver. Egenkærligheden (amour-propre) havde således sin egen vilje og sine egne motiver, der var skjult for den handlende selv, men som altid udgjorde den egentlige bevæggrund for hans handlinger. ${ }^{6}$ Begrebet egeninteresse (intérêt) præciserede i øvrigt egenkærlighedens natur ved at gøre det klart, at den rakte ud over den traditionelle beskrivelse af menneskeligt hovmod eller selvovervurdering: Fordømmelsen af det egenkærlige menneske lå simpelthen $i$, at det var "interesseret" (intéressé) i sin egen fordel. "Interesseløshed" (désintéressement) indebar modsat, at man ikke så på, hvad der tjente en selv (til gengæld var det endnu ikke sagt, at moralsk godhed kun kan bestå $\mathrm{i}$ en nøgtern respekt for moralloven - og dermed heller ikke i at stile efter, hvad der tjener andre bedst).

En lignende analyse af menneskets moralske vilkår passede godt med en teologi, der lagde vægten på introspektion og syndsbevidsthed - altså en teologi, hvor den moralske anstrengelse var i centrum. I den situation havde Jeanne Guyons mystisk inspirerede spiritualitet effekt af terapi på hendes prominente ven. Den uendelige tematisering af egen syndighed kunne fra det synspunkt, hun repræsenterede, selv opfattes som en del af den synd, der skulle bekæmpes: Den troende måtte først og fremmest lære at give slip på sig selv, inklusive et håbløst moralsk projekt, der i sidste ende var motiveret af begæret efter personlig fuldkommenhed og frygten for fortabelse. Det er dén overbevisning, der ligger bag Fénelons opfattelse af, at mennesket under det herskende vilkår skulle holde op med at søge en vished om sin egen moralske bonitet, og at freden tværtimod lå i uvisheden. Mennesket skulle overgive sig helt til Gud, ikke bare i tro på hans barmhjertighed, men i opgivelse af alle personlige ønsker og begær. Med en central formulering fra hans forsvarsskrift Explication des Maximes

6. Jf. epigrafen til La Rochefoucaulds Maximes: "Nos vertus ne sont, le plus souvent, que des vices déguisés." Maximes et Réflexions diverses (Paris: Gallimard 1976 [2006]), 43. 
des saints skulle den kristne stræbe efter en kærlighed, som hverken "frygten for straf eller begæret efter belønning" har nogen del i. Det vil sige en kærlighed, med hvilken Gud elskes for sin egen skyld, og "hverken for den fortjeneste eller for den fuldkommenhed eller for den lykke, som man bør finde i at elske ham".7

Fra den betragtning var der ikke langt til den tanke, at følelsen af gudsforladthed og uvished ikke bare ikke var en hindring for gudskærligheden, men at den ligefrem var kærlighedens betingelse. Så længe mennesket stadig nærede tillid til sin egen moralske habitus, så længe der stadig var trøst at hente i bønnens sødme, så længe man stadig havde en eller anden forventning om den evige frelse - så længe var det for Fénelon at se umuligt at elske Gud helt som man burde, dvs. alene for det, Gud er i sig selv, og ikke pga. alle de ting, som kærligheden kaster af sig: fuldkommenhed, nydelse, salighed. Forestillingen om en kærlighed til Gud under den reelt umulige, men dog logisk mulige antagelse, at han vil fordømme sine troende, blev dermed det stærkeste symbol på den ønskede renhed i kærligheden. Den kærlighed, som Fénelon talte om, ville være lige så stor, selv om Gud "skulle være uvidende om, at man elsker ham, eller havde i sinde at kaste dem, der har elsket ham, ned i evig ulykke". ${ }^{8}$ Ræsonnementet er et insisterende forsøg på at afgrænse et motiv, der ikke på nogen måde viser tilbage til den elskende selv. Med afsløringen af den egenkærlighed, der ligger i enhver konventionel fromhed, oversteg tanken om den rene kærlighed samtidig den moralske skepsis, som var accepteret af næsten alle i perioden.

En sådan hyldest til selvofferet gav sig ikke blot til kende i beundring for skikkelser som François de Sales og Broder Laurent, der i hengivelse til Gud betinget havde givet afkald på deres egen frelse. Den viste sig også i en dyb respekt for de gamle grækere og romere, der ikke havde kendt til noget egentligt liv efter døden, men alligevel havde lovprist det at ofre sig for et højere gode. ${ }^{9}$ Af samme grund er

7. Fénelon, Explication des Maximes des saints, Exposition (EP, bd. 1, 1011).

8. Ibid. Jf. den tolvte sætning tilskrevet Molinos og fordømt i bullen Coelestis Pastor (DH 2212).

9. Blandt sine helte talte Fénelon bl.a. Sokrates og Alkestis, men også epikuræerne, hvis fromhed havde været så meget desto renere, som de ikke havde ment, at guderne på nogen måde lægger mærke til deres menneskelige tilbedere; se Lettres et opuscules spirituels XXIII (EP, bd. 1, 664-71) og Lettre sur la charité (OF, bd. 3, 356). Den rene kærligheds tilhængere blev tilsvarende beskyldt for at ville elske Gud "tanquam in pura natura constituti; imo vero infra naturam puram [...], veluti nobis nullum evangelium, Christus nullus esset: instar cuiusdam Socratis [etc.]"; Jacques-Bénigne Bossuet, Schola in tuto, quaest. XII, art. XIV (CEuvres complètes, udg. F. Lachat, 31 bd. (Paris: L. Vivès 1862-1875; herefter LT), bd. 19, 739; samtlige bind findes online på http://gallica.bnf.fr). 
den rene kærlighed blevet kritiseret for at dyrke det heroiske selvoffer. At subjektet manifesterer sin suverænitet netop ved sit frie offer af sig selv, er da også et problem, der virker til nødvendigvis at hænge ved idealet om interesseløshed. Selvofferet kan ligefrem give sig til kende som den stærkeste form for selvhævdelse, en "styrkelse af selvets citadel" i stedet for dets ødelæggelse. ${ }^{10}$ Som allerede antydet var Fénelons tilgang til problemstillingen imidlertid bestemt netop af et ønske om at overvinde denne apori. Den idolisering af det moralske subjekt, som ellers truer det moralske projekt, forsøgte han at undgå med sin fremhævning af, at man ikke kan elske Gud med en ren kærlighed, hvis man samtidig bevidstgør sig sin kærlighed. En tydelig forestilling om sit eget offer modsiger simpelthen offeret som et offer. ${ }^{11}$ Fénelons dyrkelse af interesseløshedens helte i fortid og samtid står dermed i kontrast til hans fremhævning af en hengivelse, der ikke er i stand til at tematisere sig selv. Mere overordnet kan man pege på, at det moralske ideal om interesseløshed hos Fénelon fandt sin forløsning i en religiøs selvhengivelse af mystisk snarere end heroisk karakter.

Dermed er der imidlertid anslået et andet problem for begrebet om den rene kærlighed, sådan som det er formuleret hos Fénelon. Den beskrevne selvhengivelse tilsagde ganske vist ikke uden videre, at den troende skulle forvandle sig til en zombi, der handler uden at være bevidst om sine egne handlinger. Men Fénelon lagde vægt på, at den fuldkomne kun var i besiddelse af en helt igennem umiddelbar bevidsthed om sit offer, en rent momentan erkendelse af dets gudvelbehagelighed. Ethvert mærke af den gode handling i bevidstheden - alle "tydelige aftryk i hjernen" - ville nemlig være ensbetydende med den tematisering af egen godhed, som for Fénelon altid var identisk med en tilegnelse af Guds nåde. ${ }^{12}$ En sådan tilegnelse kunne bestå $\mathrm{i}$ meget lidt og faldt nærmest sammen med et menneskes bevidsthed om sin egen status. Således havde de faldne engles eneste synd været at "betragte deres egen tilstand og finde behag i den". ${ }^{13}$ Selv om Fénelon i den forbindelse måske ikke var helt lige så yderligtgående som

10. Michel Terestchenko, “'Comme un globe sur un plan...' ou la volonté déracinée dans la doctrine du pur amour de Fénelon”, Les études philosophiques, april-juni 1992, 153-177 (154).

11. Fénelon, Lettres et opuscules XI (EP, bd. 1, 605): "Pour consommer le sacrifice de purification en nous des dons de Dieu, il faut donc achever de détruire l'holocauste, il faut tout perdre, même l'abandon aperçu par lequel on se voyait livré à sa perte."

12. Fénelon, Maximes des saints, art. XXI (EP, bd. 1, 1059) ("des traces distinctes dans le cerveau”); se også art. XIII (1044).

13. Fénelon, Lettres et opuscules XI (EP, bd. 1, 604): "Ils ne firent que regarder leur état et s'y complaire; les voilà dans l'instant même précipités du Ciel et éternels ennemis de Dieu." 
Jeanne Guyon - der skrev, at "det eneste, som er rent, er det, som Gud skjuler for vores blik"14 - var han ikke langt fra at bekræfte den samme opfattelse: Menneskets synd består i selve dets tilbøjelighed til at reflektere over sit eget liv - og til dermed ikke at betragte sine egne tildragelser med samme nøgternhed, som det iagttager andres.

Indfrielsen af kravet om interesseløshed forblev altså afgørende for Fénelons tænkning: Han kritiserede ikke idealet, men ønskede tværtimod at redde det fra dets egen selvmodsigelse. Af samme grund skal det heller ikke overses, at Fénelons kærlighedsteologi for sin egen del kom tæt på noget, man kunne kalde en form for moralistisk nihilisme, dvs. undertrykkelsen af alle andre værdier end den handlendes interesseløshed (hvormed slægtskabet med kantiansk etik er ubestrideligt). ${ }^{15}$ Det samme gælder, også selv om det i artiklens tredje afsnit vil blive antydet, at den rene kærlighed i nogle af sine centrale formuleringer faktisk forblev et ideal om netop karlighed (i hvilken den egentlige værdi ikke er en handlingsregel, men det gode og det skønne). Tilsvarende kom mystikken hos Fénelon paradoksalt nok til at udgøre et stærkt sekulariseringselement i teologien: Med sin henvisning til en tilstand, hvor den troende ex hypothesi befinder sig i en verden uden løfte om evig salighed, havde han så at sige foregrebet en tid, hvor kristendommens metafysiske overbygning (bl.a. troen på det hinsides) er blevet svært reduceret - og hvor teologien så meget desto lettere er blevet reduceret til morallære. ${ }^{16}$ I det lys er det ikke så underligt, at Fénelons modstandere forstod deres opgør med den rene kærlighed som en hævdelse af den forudgående teologiske tradition.

\section{Hengivelse og begær}

Fénelons hovedmodstander i fejden om den rene kærlighed var Jacques-Bénigne Bossuet (1627-1704), fra 1681 biskop af Meaux uden for Paris. ${ }^{17}$ Som huslærer for kronprinsen havde han indtaget

14. Citeret efter Marcel Raymond, Fénelon, Les écrivains devant Dieu (Paris: Desclée de Brouwer 1967), 71f.

15. En sammenligning mellem Kant og Fénelon kan findes i Le Brun (2002), 213233; se specielt den afsluttende kommentar s. 233.

16. Denne proces er velbeskrevet i Michel de Certeau, "La formalité des pratiques. Du système religieux à l'éthique des Lumières (XVII-XVIIIe)", L'écriture de l'histoire (Paris: Gallimard 1975), 178-241. Se i øvrigt Fr. Nietzsches bemærkning i Morgenröthe, II, 132 om afløsningen i kristendommen af "das 'Eins ist noth", med "Nächstenliebe”"; Kritische Studienausgabe, udg. G. Colli og M. Montinari, 15 bd. (München/Berlin/New York: DTV/de Gruyter 1988), bd. 3, 123.

17. Den vigtigste monografi om Bossuet er Le Brun, La spiritualité de Bossuet (Paris: Klincksieck 1972). 
en lignende rolle ved hoffet som den, Fénelon spillede ved stridens begyndelse. Hans vægt i det kirkelige og politiske liv var i 1690erne stadig betydelig. Han var således del af den gruppe på tre, som mellem juli 1694 og marts 1695 nærstuderede Fénelons synspunkter. Fra udgivelsen af Explication des Maximes des saints i januar 1697 var han hovedkraften bag forsøget på at få bogen fordømt i Rom og forfatteren diskrediteret i den franske offentlighed. Det første lykkedes med den pavelige skrivelse Cum alias fra marts 1699. Alligevel har bedømmelsen af Bossuets rolle i opgøret ikke altid været nådig. Han er blevet beskyldt for at have været både enøjet og nedrig, man har kritiseret hans manglende fornemmelse for den mystiske tradition, og man har påpeget den manglende begrebsmæssige stringens $\mathrm{i}$ hans argumenter: Han var - til forskel fra Fénelon - et udpræget lyrisk temperament. ${ }^{18}$ Fra vores betragtning er det dog væsentligt, at Bossuets "pedantiske genoptagelse af Augustins etiske eudaimonisme" 19 spejler den ensidighed, man kan sige også præger Fénelons system. Dermed kommer hans tænkning til mere end blot at frembyde en kritik af den rene kærlighed som system: Den illustrerer for sin egen del blot under modsat fortegn - den bevægelse hen imod et moderne moralfilosofisk paradigme, som er denne artikels emne.

Især ét aspekt af striden mellem Fénelon og Bossuet skal optage os her: forholdet mellem diskussionen om den rene kærlighed og den middelalderlige debat om kærlighedens natur. Den klassiske fremstilling af problemstillingen i middelalderen - Pierre Rousselots afhandling fra 1908 - peger på Thomas Aquinas' tænkning som en løsning på kærlighedens dilemma mellem egoistisk begær og selvudslettende hengivelse. ${ }^{20}$ Også selv om Rousselots bog måske mere skal ses som et systematisk end et historisk værk, ${ }^{21}$ gælder det, at middelalderteologien i høj grad stræbte efter en syntese. Skolastikken er således karakteriseret af sit forsøg på at forene kravet om at elske Gud mere end sig selv med "et etisk standpunkt, som i det mindste i bred forstand var eudaimonistisk". ${ }^{22}$ Det vil sige, at mennesket rent faktisk (ifølge bl.a. Aquinas) kunne elske Gud med en kærlighed, der var større end dets kærlighed til sig selv. Men netop en sådan kærlighed gav kun mening inden for en ramme, hvor mennesket ved at elske

18. Se f.eks. Henri Bremond, Apologie pour Fénelon (Paris: Perrin et Cie 1910), 40.

19. John Burnaby, Amor Dei. A Study of the Religion of St. Augustine (The Hulsean lectures for 1938) (London: Hodder \& Stoughton 1960), 290.

20. Pierre Rousselot, Pour l'histoire du problème de l'amour au moyen âge (Paris: Vrin 1981).

21. Le Brun (2002), 410, n. 52 ("plus un plaidoyer qu'un œuvre historique”).

22. Thomas M. Osborne, Love of Self and Love of God in Thirteenth-Century Ethics (Notre Dame: University of Notre Dame Press 2005), 1. 
Gud på den måde, samtidig elskede sig selv som del af en større sammenhæng. Når det var muligt at elske Gud så højt, var det - som det udtrykkes i en 1600-talskommentar til Aquinas - fordi "Gud er et større gode for mig, end jeg er for mig selv." 23 Den thomistiske anskuelse af kærligheden formåede dermed at forene den interesseløse kærlighed med en afvisning af den "ekstatiske" kærlighed, der indebar en ophøjelse af selvofferet: Den troende elsker i Gud en virkelighed, der på én gang overskrider og definerer, hvem han selv er (Rousselot 1981, 14).

Det er samtidig klart, at en lignende løsning ikke længere virkede tilstrækkelig i 1600-tallet. Der var sket en vigtig forskydning i tematikken, som gjorde, at begge parter i striden om den rene kærlighed med nogen ret kunne gribe tilbage til den middelalderlige tradition i almindelighed og til Aquinas i særdeleshed. For Fénelons vedkommende lå det væsentlige i de distinktioner, som skolastikerne havde formuleret mellem forskellige motiver for kærligheden. ${ }^{24}$ I forreste række stod begrebet om en venskabskærlighed (amor amicitiae), der til forskel fra begærskærligheden (amor concupiscentiae) ikke søger den elskendes, men den elskedes fordel. Det var ikke svært for Fénelon at vise, at begærskærligheden hos Thomas var underordnet venskabskærligheden, ligesom hensynet til den elskende selv var underordnet hensynet til Guds ære, og ligesom den salige besiddelse af Gud (beatitudo formalis) var underordnet Gud selv som salighedens indhold (beatitudo obiectiva). Ifølge Fénelon var der dermed rigeligt belæg for den rene kærlighed i den skolastiske teologi. Højst kan man måske sige, at mystikernes umulige antagelse fra hans synsvinkel tjente til at operationalisere en distinktion mellem egeninteresse og interesseløshed, som allerede fandtes i skolastikken.

Bossuet angreb for sin del enhver anvendelse af de skolastiske distinktioner på den troendes indre liv. Han medgav ganske vist, at teologer siden Anselm havde skelnet mellem på den ene side menneskets salighed som et egennyttigt motiv og på den anden side det, som er tilbørligt og retfærdigt i sig selv. ${ }^{25}$ Han hævdede endda, at det ikke var svært at finde eksempler på den umulige antagelse hos skolastikerne, specielt Johannes Duns Scotus. ${ }^{26}$ Men i ingen af tilfældene, hvor middelalderteologerne havde lagt vægt på at skelne, havde de også ønsket i praksis at adskille de forskellige motiver. ${ }^{27}$ Tværtimod

23. Louis Bail, La théologie affective ou saint Thomas en méditation (Paris 1659), 512.

24. Fénelon, Dissertatio de amore puro (OF, bd. 3, 420-571, især 420-454).

25. Bossuet, Instruction sur les états d'oraison, traité I, livre X, n. XXIX (LT, bd. 18, 647).

26. Ibid., traité I, livre IX, n. III (581).

27. Idem, Réponse à quatre lettres, n. XV (LT, bd. 19, 559). 
hørte de to aspekter sammen. For Bossuet betød det, at det var på grænsen til det meningsløse at sige, at man elskede Gud uden at begære ham. Ud over traditionsargumentet henviste han til det forhold, at ingen relation mellem mennesker ville kunne bære en kærlighed, der var helt og aldeles interesseløs. Det ville fra hans synspunkt sige en kærlighed, som i sidste ende slet ikke kerede sig om den elskede: "Jeg, et menneske, vil gerne have mig frabedt at blive elsket, hvis det er til dén pris." 28 Dermed lagde Fénelons modstander i første omgang vægten på syntesen i den skolastiske teologi: Man søger nok Gud for Guds egen skyld, men ikke uden altid også at søge fællesskabet med ham i evigheden.

Havde Bossuet ikke gjort andet, ville det have været muligt at betragte hans opgør med Fénelon simpelthen som en reaktion på en problematisk teologisk innovation. Bag ved Bossuets hævdelse af den nødvendige sammenhæng mellem hengivelse og begær lå der imidlertid en påstand om begærets primat, som i sidste ende - $\mathrm{i}$ hvert fald ifølge Fénelon - helt umuliggjorde hengivelsen. Også her kunne den aldrende biskop finde belæg i den forudgående tradition, mere præcist i den klassiske tanke om menneskets naturlige længsel efter lykke. Et særlig prægnant belæg for den forestilling er at finde i Augustins De Trinitate (XIII, 5[8]), hvor kirkefaderen udfolder lykkebegærets universelle karakter: Mennesket vil være lykkeligt, det kan ikke lade være med at ville det, og alt, hvad det i øvrigt vil, vil det med den hensigt. "Alt gør man for at blive lykkelig," gentog Bossuet, "dét er så at sige naturens grund, som nåden altid forudsætter." ${ }^{29}$ Han havde uden nogen tvivl ret i, at lykkebegæret hos Augustin ikke - som Fénelon ellers hævdede det - simpelthen definerer en understrøm i menneskets psyke, en slags biologisk trang, som det rent faktisk er muligt at overvinde. ${ }^{30}$ Tværtimod kan man sige, at begæret ifølge Aquinas såvel som ifølge Augustin udgjorde det inderste af den menneskelige vilje, det stof, som hver enkelt viljeshandling er formet af (Rousselot 1981, 8ff.).

28. Idem, Instruction, Add. et corr., n. VIII (LT, bd. 18, 671). Jf. modsat Fénelons forsøg på at begrunde idealet om den rene kærlighed i det syndige menneskes krav på at blive elsket "en sorte que le monde entier lui soit sacrifié"; Lettres et opuscules XXIII (EP, bd. 1, 664).

29. Bossuet, Préface sur l'Instruction pastorale, partie II, sect. X, n. CXIV (LT, bd. 19, 279). Jf. også Réponse, n. X (543): "Si c'est un acte humain et véritable, on ne le peut faire que pour être heureux."

30. Fénelon, De amore puro, Ia pars, c. V (OF, bd. 3, 440) ("propensio quaedam ad beate vivendum"). Fénelons forhold til Augustin og den augustinske tradition var i øvrigt komplekst; jf. min ph.d.-afhandling "A Love Beyond Desire? Investigations into the Theologies of Jansenius and Fénelon" (Aarhus Universitet 2009). 
Igen stiller spørgsmålet sig imidlertid om graden af overensstemmelse mellem den forudgående (senantikke og middelalderlige) tradition og parterne i striden om den rene kærlighed. Det er således ikke kun Fénelon, der har fundet en problematisk forskydning i Bossuets anvendelse af det antikke lykkeparadigme: Den rene kærligheds modstander behandlede jævnligt béatitude som et synonym for félicité. Som det er blevet påpeget, forårsager det den mistanke, at han betragtede menneskets lykke som en rent sanselig størrelse (Le Brun 1972, 330). Bossuets hævdelse af lykkebegæret ligner i den henseende den jansenistiske fortolkning af det augustinske begreb delectatio. At vi altid, som Augustin skrev, vil det, som behager os mest ("quod amplius nos delectat"), var hos Pascal udtryk for en rent analytisk sandhed: At ville noget og at behages af noget kan med nogen ret betragtes som synonymer. Men derfra var det alt for let at glide til den helt igennem empiriske - og noget tvivlsomme - påstand, at mennesket $\mathrm{i}$ alle sine handlinger er en slave af kødelig (eller åndelig) nydelse. I analyserne både af beatitudo og af delectatio (og af det ligeledes augustinske begreb fruitio) kan man således tale om en problematisk glidning fra det ontologiske til det psykologiske plan, dvs. fra et udsagn om viljens eller den menneskelige naturs struktur til et udsagn om den troendes motiver eller følelsesliv. ${ }^{31}$

Det er på den måde, det er muligt at betragte Bossuets synspunkt som en spejling af Fénelons. Hvor den forudgående tradition var tvetydig i sin sammenblanding af ontologiske og psykologiske temaer, benyttede stridens parter tvetydigheden til at argumentere for hver deres mere entydige position. Man kan også sige det sådan, at Bossuet accepterede spørgsmålet om den interesseløse handling som den grundlæggende forudsætning for diskussionen. Samtidig hævdede han lige præcis den konsekvens, som det var Fénelon alt om at undgå: at menneskets kærlighed til andre kun kan være en funktion af dets kærlighed til sig selv. Den traditionelle augustinske forestilling om, at mennesket er drevet af en længsel efter at udfylde det eksistentielle hul, som syndefaldet har efterladt, blev dermed først og fremmest til et belæg for menneskets grundlæggende selviskhed (hvor man også modsat havde kunnet læse det som et udtryk for menneskets henvisthed til sin omverden). Det er denne opfattelse af, at mennesket i sidste ende kun kan forholde sig instrumentelt til verden, der gør Bossuets system problematisk. Hvis vi skal kritisere begrebet om den rene kærlighed, må det altså ske på en måde, så vi

31. Le Brun (1972), 342. Det er tilsvarende blevet sagt, at hvor Fénelon begik en ontologisk, begik Bossuet en psykologisk fejltagelse; Bremond (1910), 446, n. 1 (med henvisning til William George Ward). 
undgår at blive taget som gidsler af et lige så ufrugtbart modbegreb. Betingelsen for at kunne dét er formentlig, at vi bevæger os bort fra den kartesianske præmis, som reelt betingede begge de positioner, vi nu har set på.

\section{Kærlighedens fænomenologi}

Et opgør med det beskrevne interesseløshedsparadigme kan findes hos en række nutidige teologer og filosoffer. Fra teologisk hold kan nævnes John Milbanks oplagte angreb på moderne moraltænkning eller Bo Kristian Holms og Niels Henrik Gregersens diskussion af begreber som gavegivning og generøsitet. ${ }^{32}$ Fælles for disse bidrag er en teologisk besindelse på skabelse og nåde - altså på mennesket som et væsen, der ikke bare giver sig selv, men som først og fremmest selv er givet. Samtidig er der tale om et forsvar for, at der finder en slags eruption af uselviskhed sted inden for relationer mellem mennesker, der i højeste grad er bestemt af gensidighed. I den sammenhæng er det værd - som omdrejningspunkt for artiklens sidste afsnit - at henlede opmærksomheden på Robert Spaemanns arbejder. Foruden en væsentlig bog om lykkebegrebet og etik tæller hans udgivelser en af de vigtigste monografier i Fénelon-forskningen. ${ }^{33}$ Hans tekster tilbyder dermed på samme tid en uomgængelig analyse af striden om den rene kærlighed og et interessant forsøg på at overvinde den moralfilosofiske misere, som fejden accentuerede.

Allerede i sin bog om Fénelon interesserede Spaemann sig for en vej ud af den frugtesløse modsætning mellem moralisme og eudaimonisme. ${ }^{34}$ Hans interesse var ledsaget af et ønske om at genlæse Fénelon fra et ontologisk perspektiv. Den sene Fénelon havde således ifølge Spaemann lært at skelne mellem det psykologiske og det ontologiske plan i kærligheden, hvilket havde tilladt ham at tale om selvtran-

32. John Milbank, “The Midwinter Sacrifice: A Sequel to 'Can Morality Be Christian?" Angelaki, 6, 2 (2001), 49-65; Niels Henrik Gregersen, "Generøsitetens teologi", DTT 71 (2008), 77-99; Bo Kristian Holm, "Justification and Reciprocity: 'Purified Gift-Exchange' in Luther and Milbank", Word, Gift, Being: Justification - Economy - Ontology, red. B.K. Holm og P. Widmann (Tübingen: Mohr Siebeck 2009), 87-116.

33. Robert Spaemann, Reflexion und Spontaneität. Studien über Fénelon (Stuttgart: W. Kohlhammer 1963); Glück und Wohlwollen. Versuch über Ethik (Stuttgart: Klett-Cotta 1989).

34. Jeg bruger termerne i overensstemmelse med Spaemann (1963). Med "moralisme" hentydes der til en etik, der løsrevet fra enhver naturlig tilbøjelighed først og fremmest er negativt defineret, nemlig ved sit bevidste brud med al egeninteresse. 
scendens ikke kun som offer, men også som en opfyldelse af den menneskelige natur (Spaemann 1963, 47f.). Endnu mere væsentligt fandt den tyske filosof en fænomenologisk indsigt hos ærkebiskoppen, som han kunne beskrive som den egentlige nøgle til kærlighedens dilemma: Enhver menneskelig handling eller beskæftigelse (actus) har nødvendigvis en genstand eller et mål (finis). Det definerer dermed altid på forhånd menneskets indre liv, at det peger ud over sig selv. Hos Fénelon fungerer betragtningen som en afvisning af, at beatitudo formalis kan være menneskets $\mathrm{i}$ absolut forstand endelige mål: Også saligheden må som en tilstand i sjælen have en genstand uden for sig selv. ${ }^{35}$ Spaemann læser ræsonnementet som en foregribelse af Max Schelers argument imod oplysningsfilosoffernes selfish hypothesis: Jagten på lykke (som det siges et andet sted) "rider på ryggen af" affekter og viljeshandlinger, hvis indhold er noget andet end menneskets egen lykke (Spaemann 1989, 32). På den måde må f.eks. Humes påstand om, at vi aldrig tager et skridt uden for os selv, tilbagevises alene på fænomenologiske præmisser. ${ }^{36}$

Det er klart, at påpegningen af kærlighedens "objektivitet" hos Fénelon (Spaemann 1963, 95) eller af dens "ekstatiske" karakter ${ }^{37}$ kan siges noget håndfast at skrive ærkebiskoppen ind i det 20. århundredes filosofiske kontekst. Det er ikke desto mindre værd at insistere på den afgørende distinktion mellem indhold og anledning, som den nævnte læsning forudsætter. Spaemanns kritik af Bossuets lykkebegreb og af jansenisternes begreb om delectatio beror således på den observation, at de forestillede sig troen og kærligheden, ja Gud selv som legitime midler til at nå saligheden som det endelige mål. Men dermed havde de ifølge Spaemann reduceret genstanden for kærligheden til en ren anledning, sådan at den relevante nydelse (forstået rent kausalt som en effekt) lige så godt kunne have haft en hvilken som helst anden årsag (hvorved kærligheden kommer til at beskrive en jagt på sanselig stimulering). I Leibniz' svar på kærlighedens dilemma er actus-finis-strukturen fra Fénelons tekster til gengæld tydelig: "At elske er at være sådan sindet, at du finder din vellyst i en an-

35. Fénelon, De amore puro, Ia pars, c. II (OF, bd. 3, 425ff.). Fénelon taler tilsvarende om, at amor er primær i forhold til desiderium, dvs. at mennesket forholder sig til genstanden for sin kærlighed, før det forholder denne genstand til sig selv. Begge ræsonnementer er hentet fra Aquinas. Jf. Spaemann (1963), 38f., n. 57: "Moralismus und Eudämonismus werden hier [...] durch eine 'phänomenologische' Ontologie der menschlichen Handlung aufgehoben."

36. R. Spaemann, Schritte über uns hinaus. Gesammelte Reden und Aufsätze I (Stuttgart: Klett-Cotta 2010), 7.

37. Denise Leduc-Fayette, Fénelon et l'amour de Dieu (Paris: P.U.F 1996), 53. 
dens lykke."38 Den nævnte lyst har ikke kun en anledning, men også et indhold, hvilket vel ikke gør den interesseløs, men ikke desto mindre understreger, at kærligheden - selv som affekt - er defineret af en genstand uden for den elskende selv. Hvis genstanden var en anden, ville også den elskendes glæde være en anden.

Det er især dén indsigt, som Spaemann udfolder i sin bog om lykke og etik fra 1989. Efter at have udlagt den uheldige dikotomi mellem eudaimonisme og anti-eudaimonisme, ${ }^{39}$ overvejer han her, hvordan det er muligt at forene lykkebegrebet med et begreb om uselviskhed: Hvor mennesket i sine handlinger og affekter altid er ude i verden, har jagten på lykke vel i udpræget grad den handlende selv som sit egentlige mål? Spaemanns svar på indvendingen består i en distinktion mellem to forskellige niveauer, der tillader at adskille lykkebegrebet fra alle de forehavender, mennesket kan give sig i kast med: Lykken er ikke et mål i livet mellem andre mål eller en slags gevinst, som man kan handle sig til og måske købe for dyrt. ${ }^{40} \mathrm{I}$ det hele taget rummer lykkebegæret ikke nogen egentlig retningsbestemmelse af viljen, sådan at det forklarer noget, hvis man siger, at man handlede på en bestemt måde for at blive lykkelig. Snarere kan man sige, at menneskets forskellige forehavender i livet forholder sig til dets lykke som dele af et billede til billedet som helhed. Kun af den grund er det muligt at betragte livet under synsvinkel af begrebet lykke uden at gøre f.eks. menneskelige handlinger og relationer til et simpelt middel i jagten på lykken som mål.

Det er klart, at en sådan niveaudeling indbyder til en vis relativering af menneskelige forehavender: Det kommer ikke længere kun an på, hvorvidt det, som den handlende har i sinde, lykkes, men også på den plads, som de givne handlinger (forstået aristotelisk som praxis og ikke som poiesis) indtager i personens historie. Dermed er det dog ikke sagt, at disse handlingers intentionale struktur er blevet ophævet: Hvis livet er et skuespil, står og falder dets succes med, hvordan der spilles i den enkelte situation. Og hvor en rigtig skuespiller kan nøjes med at fingere en bestemt handling - f.eks. at reparere en sko kræver den rolle, som ethvert menneske spiller, først og fremmest oprigtighed. Ingen kan altså udfylde sin rolle i livet uden at være til stede med et virkeligt engagement i det, det drejer sig om. I livet kan man f.eks. ikke være skomager uden faktisk at producere sko, dvs. uden at være involveret i en praksis, der bringer en uden for en selv.

38. "Amare est eo esse animo, uti in alterius felicitate sis reperturus voluptatem tuam." Citeret efter Spaemann (1963), 201.

39. Spaemann (1989), 9-11. Se også (med reference til Spaemann) Milbank (2001), 51.

40. Det følgende refererer til Spaemann (1989), 37-43. 
På den måde kan den traditionelle modsigelse mellem lykkebegær og "ekstatisk" kærlighed i nogen grad skrinlægges. Det selvbiografiske projekt er vel uopgiveligt, men er alligevel ontologisk sekundært i forhold til et mere oprindeligt engagement i verden. ${ }^{41}$

Spaemanns betragtninger skal måske ikke ses som en decideret løsning på den interesseløse kærligheds problem, men de antyder, hvordan det er muligt mere overordnet at kritisere det paradigme, som i høj grad kendetegner moderne moraltænkning. Mennesket er ikke simpelthen og uden videre et selvisk væsen, men uselviskheden er på den anden side fortrinsvis ontologisk og ikke moralsk bestemt. Ikke mindst i protestantisk teologi er det stadigvæk i vid udstrækning en forestående opgave at implementere den indsigt. Ligesom begrebet om den rene kærlighed tog form på klangbund af en stadig skarpere distinktion i katolsk teologi mellem det naturlige og det overnaturlige, har den protestantiske afgrund mellem natur og nåde nemlig udgjort en frugtbar jord for interesseløshedsidealet. Særlig Karl Holl og hans disciple opdyrkede den radikale, men uopfyldelige fordring om selvopgivelse som indbegrebet af evangeliets krav til mennesker (Holm 2009, 110-112). Det er problematisk, hvis evangeliet dermed betragtes som en modsigelse af enhver naturlig længsel og af ethvert selvbiografisk projekt, dvs. som en helt overordnet fordømmelse af det naturlige liv. Som det er blevet antydet i artiklen, er det kun en mystisk inspireret praksis, der ville give et lignende bud om selvopgivelse mening. I fraværet af en sådan praksis er den nævnte fordring ikke bare morbid, men desuden helt igennem abstrakt. ${ }^{42}$

Til sidst står den indvending tilbage, at den omtalte glidning fra det ontologiske til det psykologiske plan faktisk betegner en gevinst i refleksivitet. Når først spørgsmålet om menneskets inderste motivation er stillet, er det måske umuligt igen at se bort fra: Det findes herefter altid som en nagende tvivl, som det ikke er til at glemme. Det er da heller ikke meningen at antyde, at den mistænksomhed over for alle menneskelige motiver, som blev dyrket af reformatorerne og de franske moralister, kun er forfejlet. Ikke desto mindre har nærværen-

41. De nævnte overvejelser belyser i øvrigt den modsigelse, som Bossuet antydede i mystikernes forkærlighed for den selvbiografiske genre: De "nye mystikere", som skarpt kritiserede enhver refleksivitet, producerede en omfattende litteratur, hvor de var de første til at reflektere over deres eget liv. Hvis det er rigtigt, at denne kritik beror på en misforståelse, er det kun, fordi selvhengivelse og selvbiografisk interesse rent faktisk ikke ophæver hinanden. Jf. Le Brun (1972), 490.

42. Inden for interesseløshedsparadigmet er det i øvrigt vanskeligt $i k k e$ at hævde fordringen om fuldstændig selvopgivelse. I så fald mangler man nemlig et kriterium for, hvornår man rent faktisk skal leve efter idealet, og hvornår man ikke skal, "when to live and when to give"; Milbank (2001), 54 (igen med reference til Spaemann). 
de artikel netop forsøgt at vise, at den centrale begrebsdannelse i denne forbindelse - begrebet om interesseløshed - ikke betegner et ubestrideligt filosofisk fremskridt frem mod større begrebsmæssig klarhed. Tværtimod er det umuligt at hævde et sådant ideal (eller modbegrebet om menneskets naturnødvendige selviskhed) med nogen grad af stringens, uden at det fører til urimelige konsekvenser. Dertil skal lægges, at opdyrkelsen af interesseløshedsidealet kan betragtes som et vigtigt afsnit i historien om den vestlige tænknings afsked med teologien. Udviklingen af en anden måde at tale om den verden på, som etik og moral beskæftiger sig med, er dermed både en filosofisk og en teologisk nødvendighed. 